\title{
Is the Fate of Africa a Question of Geography, Biogeography and History?
}

\author{
Emmanuel Ifeanyi Ani \\ Department of Philosophy and Classics, University of Ghana, Legon, Greater Accra, Ghana \\ Email: mabrowest@yahoo.com,emmanani@ug.edu.gh
}

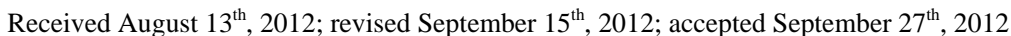

\begin{abstract}
This paper dwells on the debate on the question of what is/are responsible for African underdevelopment and, by extension, what will influence African development. The debate currently dwells on how much of development is human and how much is environmental, extraneous and beyond human control. Joseph Agbakoba thinks that development involves both nature and human agency, acknowledges the effect of nature, equally sees philosophy as a critique of worldview and ideology, and African philosophy as saddled with the critique of the African worldview and ideology, which he sees as malfunctioning in the context of the modern African civic society imported from Europe and needs certain adjustments. In other words, he sees development in Africa as not beyond human control. J. Obi Oguejiofor attempts to refute Agbakoba's claim that worldview has anything to do with the African predicament, and concludes that the African predicament is as a result of geography, biogeography and history, but his advancement of these factors as being solely responsible for the African predicament completely ignores the human agency in development and lands him in determinism raising the question of the very relevance of African philosophy to African development. Conceptual analysis informs the dominant method of the paper.
\end{abstract}

Keywords: Africa; Development; Predicament; Geography; Human Agency; Worldview; Fatalism

\section{Agbakoba and African Philosophy as Critique of African Worldview}

In his article "Philosophy and Traditional African Ethics: The Problems of Economic Development”, Joseph C. Agbakoba $(2003,2009)$ starts with the relationship between philosophy (considered as an expression of fundamental philosophical values) and development, this here particularly understood in its economic sense. For him, philosophy may be defined as a worldview (Weltanschauung) of a people (2003, 2009: p. 550); in this sense, philosophy depicts the actual metaphysical, epistemological, ethical, aesthetic, etc. beliefs of a people - the supreme beliefs of a people and their derivativesall of which constitute the dominant beliefs that underpin the social institutions, policies and social practices of a people. The author explores the meaning of development and then goes on to evaluate the views and perspectives that tend to argue against philosophy in its broadest sense (that is philosophy considered simply as a worldview or as a system of values) occupying a distinct and significant role in development, in order to argue that philosophy has indeed a very distinct and significant role to play in the process of development, even in its economic sense. In order to demonstrate this important point, the author explores what he considers the impact of the traditional African ethical outlook and values in relation to the economic activities and the process of economic development in contemporary Africa.

In particular, Agbakoba (558) refers us to Oguejiofor's observation of two ethical values of traditional African societies: particularism and materiality: particularism in the sense that the feeling of brotherhood which is felt in the traditional African community is not consistent beyond the boundaries of the particular community or tribe, withdrawing along with it com- mitment, allegiance and honesty virtues and values in dealing with other people (Agbakoba, 2003: p. 574), and materiality in the sense that economic achievement and the acquisition of wealth are so entrenched in the traditional African worldview that it is even a measure of an individual's afterlife and ancestral membership (Oguejiofor, 1996: pp. 26-32). Thus materiality is given spiritual approval to the extent that its methods of acquisition tend to be relegated to the background. Because of the particularism of traditional community virtues, the modern African living beyond his immediate community finds himself in an ethical jungle and a social sea with a dysfunctional compass (Agbakoba, 2005: p. 575) where he pursues his self-interest (and that of his community brothers on a secondary level) in a narrowly defined manner provided he does not breach the laws regarding his kith and kin. As we shall see, the combined effects of particularism and materiality exploded on contact with colonialism, independence and the imperative of nationalism, national patriotism and nation building, since in terms of particularism the individual is primarily tied to the aprons of his immediate tribe and community, thus rendering the national and state project in Africa a near empty shell. One direct consequence of this clash between two worlds is what the Igbo call imammadu, in which nepotism almost completely replaces competence viz a viz national development. Materiality keeps driving further nails into this nationalist coffin by ensuring that the contemporary African does anything to plunder the modern civic African state and society in order to demonstrate his materiality in his primordial origins (Ekeh, 1975: p. 105; Ani, 2009: p. 79). The important thing here is that Agbakoba emphasizes that these values are being forced upon a societal structure and scope for which they were not made and therefore need to be revisited. 
Agbakoba regards these as ethical fallouts from the clash between traditional African worldview and colonialism which has led to malfunctioning ethical values for modern African political and economic society and sees African philosophy as tool for revisiting these ethical values, and the (more foundational) African worldview upon which the ethical value-system is based, in lieu of development understood as self-realization.

\section{Oguejiofor and Geo-Historical Determinism}

In his article "Is the African Worldview Responsible for the African Predicament?”, J. Obi Oguejiofor denies that African development has anything at all to do with the African worldview, that there is anything wrong with the African worldview, and that the African worldview is responsible for African underdevelopment (Oguejiofor, 2009: p. 1). He goes on to conclude that African underdevelopment is as a result of geography, bio- geography and history (2).

Oguejiofor begins by analyzing the concept of worldview. For him, worldview is an unconscious development and he distinguishes it from philosophy of life, which he says is consciously chosen, and equally distinguished worldview from ideology because ideology is a (political) set of ideas about how society ought to be, not how it actually is, and is usually encapsulated in slogans of action for the common man, as distinct from worldview which will have to furnish universal reasons for this slogan of action, including the place of gods, spirits, deities, man and lower creatures, etc. According to him:

Thus we can talk of communist ideology, socialist ideology and capitalist ideology. These are by no means the same as worldview. No doubt, we can in a stretched connotation speak of capitalist worldview or socialist worldview. But then we would in these instances be talking of metaphysics, a conception of the world, including the position and roles of God, the deities, man and lower creatures in a cosmological scheme (Oguejiofor, 2009: p. 3).

Oguejiofor thus objects to Agbakoba's inter-use of worldview and ideology, and distinguishes ideology from worldview by saying that ideology is about practical calls/slogans to action which do not have to include the accompanying theories and beliefs in the universe as is seen in worldview. But this distinction misses the point: ideology is distinguished, but not different as he claims above, from worldview. Wiredu (1980: p. 52) recognizes this link when he sees ideology as “... a set of ideas about what form the good society should take, and any such set of ideas needs a basis in first principles, which is where philosophy comes in.” Surprisingly in his very next line Oguejiofor makes a U-turn by acknowledging that ideology can be stretched from the political to the metaphysical to get a worldview. Thus a worldview is a foundation for an ideology: it provides the explanatory instruments for this ideology. Oguejiofor also writes that ideology is okay for the less informed masses and only hard cooked intellectuals will press for sublime and ultimate explanations for a slogan of action (2009: p. 3). So it follows that an ideology finds its explanation, or is understood, in a worldview. It is in this sense that Agbakoba uses both interchangeably.

According to Oguejiofor (2009: p. 3):

It (worldview) is different from a philosophy of life or a motto. A philosophy of life is often couched in an inspirational saying or an idyllic relationship with the world or with fellow men. It is different from worldview because it is consciously chosen, but the worldview of a people develops over time, irespective of the philosophy of life of the individuals or groups of individuals that make up the community.

Could the worldview of a people have developed irrespective of the individuals or groups of people in that community? If not the people, then what developed it? Even if Oguejiofor is saying that African conceptions of the Supreme Being, deities, man, the lower animals, were all arrived at unconsciously, is the conscious not a major gateway to the unconscious? Imagine that each of these entities or concepts in African cosmology has series of explanations and theories as to its supposed existence, and all these theories emerged from nowhere without human agency. These theories about the world around us did not come directly from heaven (or hell) and enter into the human subconscious without at least being thought of. It seems contradicttory to say that man's efforts to come to terms with his environment and fashion explanations for these over time were actually carried out without him. Clearly what informs Oguejiofor's denial of philosophy and consciousness of worldview is the limitation of philosophy to individual and critical activity by Professional African philosophers who do not agree that a worldview is also a philosophical way of seeing things. But this overlooks the possibility that what we call worldview today could have arisen from the evolutionary aggregation of the cogitations of individual members of society over time. This cogitation, or rather its momentous result, must not be perfect, can never be perfect; it improves on itself with time. And this gradual improvement is facilitated by the critical element of individual cogitations viz a viz worldview in the light of new frontiers of insight, culture and worldviews, an element that Oguejiofor tries to rebuff. Therefore, worldview is human and conscious, and therefore, philosophical.

Next, Oguejiofor, like William Abraham, states that worldview emerges from man's first encounter with nature, is encapsulated in the myths of origin of a particular people (5), and therefore, African worldview developed from the pristine conditions of the ancestors of present day Africans (Oguejiofor, 2009: pp. 4-5). Here he gives the impression that worldview is forever static and remains glued to the "beginning of the world". What he seems to imply therefore is that even though worldview emerged from the very first encounter with reality, it cannot change with changing reality. If worldview is static, then philosophy cannot be a critique of worldview, such critique being meaningless and already defeated. But Oguejiofor contradicts himself (along with William Abraham on whom he relies here) in this regard. If, as he asserts, worldview arises out of living conditions and is always influenced by them (5), then it is inescapable that worldview must continue to evolve with changing conditions, and not remain tied to the very first living condition. It is, therefore, bogus to say that Africans approach reality today according to the method of understanding of their very first ancestors. In any case towards the end of his work, Oguejiofor is to make a U-turn on the pristine nature of worldview by commenting on how "... changeable and nebulous it is." (11).

Oguejiofor goes into a narration of the threats of natural disaster, environmental hostility and the African's superstitious reaction to them in setting up rituals and deities, which leads him to the conclusion, not just that nature's hostility is responsible for African underdevelopment, but that this natural hostility is correlated to the level of superstition in Africa (Oguejiofor, 2009: pp. 6-7). According to him: 
The picture that filters out of the above is a situation where life (in Africa) is threatened by many factors and forces: poverty, usual natural disaster, geographic unpredictability, absence of many economic endowments. Natural scientific progress becomes really slow in such circumstances. These in turn gave rise to a conception of evil forces as responsible for many incomprehensible occurrences in man's life (Oguejiofor, 2009: p. 7).

If we are asked to choose between, on the one hand, ecological upsets like the droughts of Central/Eastern Africa, a recent mudslide in Uganda that killed about eighteen people (BBC News Africa, 2012: par. 1), the recent flooding in Nigeria that momentarily lowered oil production, and, on the other hand, environmental disasters ranging from tsunamis, tornadoes, hurricanes to earthquakes that have so far left Africa literarily untouched, which would we see as the types of natural disasters that have enough magnitude to destroy thoroughly and to paralyze and numb the mind? Which of these categories of disasters ought to more vividly provide an impression of "angry gods" and thus more deeply compel superstition? Which is a greater persuasion to the psychology of resignation? From time immemorial, Japan has sat atop frighteningly faulty subterranean tectonic plates (Waldie, 2012: par 1) that have made the most destructive and bloody earthquakes in human history a house-hold affair, routinely taking away amounts of lives that are equal to some wartime mortality rates, and causing national economic losses of magnitudes that tax the imagination. Most importantly, we might consider the sheer psychological challenge involved; especially when we consider that a superstitious reading of the enormity of its various natural disasters is likely to conclude that the very existence of Japan is basically a providential error. The Scandinavian and Nordic tribes, ancestors of Western Europe, and the Siberian Russians come from historical and geographical backgrounds of the most extremely unfriendly weather conditions in the world: climatic conditions dominated by extremely low temperatures and heavy layers of snow for most parts of the year, making it virtually impossible to do anything with the soil. Perhaps, this sped up the discovery of iron and hence technology. History and common sense thus seem to suggest quite the contrary: that natural hostility is the driver of human ingenuity, scientific and technological innovation, hence the famous dictum "Necessity is the mother of invention”. But more importantly, Oguejiofor's assumption that African geography and environment are more hostile to development compared to elsewhere, along with the implication that the geographical friendliness of respective regions of the world is in direct proportion to their level of development, is not just too reductionist but out rightly false.

If we are to consider natural disasters, then nature pampered Africa. Besides, it is not natural hostility but man's reaction to it that determines development. Oguejiofor energetically describes how natural hostility has led to conceptions of evil forces, in other words, to a superstitious worldview, but he puzzlingly denies that philosophy can be a critique of this world view. In this respect, we may ask: If development is a purposeful and goal-oriented change, then how will a pervasive tendency toward extra-natural rather than scientific or logical explanations lead to any form of development? And should philosophy not be a critique of superstition? The African superstitious reaction to nature (or worldview), which Oguejiofor observes of pre-colonial Africa, can be seen as evolutional and due for re-orientation, as happened in Europe during the Ren- aissance and scientific ideological revolutions. It is this same worldview that he shields from any attempted critical inquiry. Again, it is the human agency that has to intervene to correct an initial and naïve impression created by contact with nature's hostilities. Indeed, let us look at what Oguejiofor thinks of worldview in general and the African worldview in particular.

Oguejiofor argues that condition affects worldview, but worldview cannot affect condition. For him:

A particular worldview develops from a particular condition, and it is not the worldview that causes the condition in the first place, otherwise, we would understand it to be made in heaven (or hell) and dropped into the particular community, which holds it. Hence the African condition gave rise to the African worldview, and it is shaped by it (Oguejiofor, 2009: p. 8).

This is pure determinism. Fatalism is a more specific terminology since its only logical outcome is resignation. What Oguejiofor is saying is that we are entirely at the hands of nature. Nature shapes man, man cannot shape nature. This is very unlike Serequebehran's quoting of Senghor's view that: “... the true and proper characteristic of Man is to snatch himself from the earth... to escape in an act of freedom from his "natural determinations." It is by liberty that man conquers nature and reconstructs it on a universal scale, that man realizes himself as a god...” (Serequebehran, 1994: p. 51).

Oguejiofor supports his argument by reference to the United Nations Index of Human Development, where he urges one to notice that countries of the same region share more or less the same level of development compared to other parts of the globe, and concludes that there must be "... something more at play, something linked with where they are found, the context of their existence which is such that all nations living around the same region have more or less the same level of economic development”, and concludes by asking how this can be an issue of worldview (Oguejiofor, 2009: p. 8). But what is the reason to suppose that general parity in regional development is a result of mere geographical and climatic similarity and not the prevalent worldviews in these respective regions? And how correct is his supposition of parity of regional development from the UN Index? Is Jamaica not a few miles from Florida, or Haiti from the USA? How far is famine-embattled Zimbabwe from South Africa? Why is the first Mexican city that you set your eyes on so markedly different upon crossing the US/Mexican border? Are these due to region or climate? The same United Nations Human Development Index shows that Afghanistan, Bangladesh, Bhutan, Burma, Cambodia, East Timor, Laos, Maldives, Nepal, Yemen, Vietnam, Tajikistan, Uzbekestan, Sri Lanka, Kyrgyzstan, Mongolia, are all on roughly the same category with many sub-Saharan African countries, but they are in EuroAsia, and nestled around countries of "Very High Human Development” as immediate next-door neighbours. And why are rankings of "economic" development also highly correlative with rankings of "human" development (whose major component is education)?

Oguejiofor describes Agbakoba's view as belonging to the occupational hazard of an independent philosopher who thinks that ideas and ideas alone can change the economic lot of men (8), but this misunderstands Agbakoba's theory, which acknowledged the influence of geography and history in addition to human agency in human development (he even dedicated ten pages of his article to treating Jared Diamond's geographical narrative), but pointed out that geography and history are not all there is to human development or under-development (Agba- 
koba, 2003: p. 564). Oguejiofor's criticism, therefore, is misplaced. Oguejiofor then goes ahead as thus:

In economic history, the most important factor is the availability of resources (including mineral, agricultural, human, etc), stability of socio-political context, influences from outside, efficient management, and most of these are highly determined by the specific geography of a particular region. You cannot build cement houses if cement is lacking in your region. You cannot erect stone buildings if there is no rock to quarry stones from. Human beings have an uncanny ability to adapt their lives to their natural circumstances (8).

The last sentence of the above citation is meant to sum up the rest of the citation, but it can also contradict it: If the ability of human beings to adapt to their natural circumstances is uncanny, then it means that they can also influence these natural circumstances and not just the other way round. Apart from the implication of the above citation that even political stability is also dependent on geography, Oguejiofor is, by implication, suggesting that the mineral and human resources necessary for the invention of respective technologies are nowhere found in Africa, which is why the ideas of developing them do not exist. But what led to the scramble for Africa in the first place? Was "civilizing mission" enough to invite the imperialists? No, Africa possesses 99 percent of the world's chrome resources, 85 percent of its platinum, 70 percent of its tantalite, 68 percent of its cobalt, and 54 percent of its gold, among others. It has significant oil and gas reserves. Nigeria and Libya are two of the leading oil producing countries in the world (Eisele, 2007: par 2). Many African countries follow the strategy of exporting as much (of these natural resources) as they can (Agazzi, 2012: par 1). Japan has to import $84 \%$ of its natural resources and is only $16 \%$ energy resource self-sufficient... It is the world's largest importer of LNG, second largest importer of coal and the third largest net importer of oil (US EIA, 2012: par 1). These resources have always been lacking and did not just run out recently (Austin, 2011: par 2). It is also the world's third largest economy (CNNMoney, 2012) and a tiny (geographical) island. Peter Temin observes that "The influence of natural resources has declined over time. Resources either are endogenous-a creation rather than a cause of economic growth-or irrelevant to economic growth. The United States provides an example of the former condition; Japan, of the latter” (Temin, 1998: p. 408).

How does African geography specifically inhibit African development? Read Oguejiofor:

The first of these, geography, may not appear important at first sight until one stops to examine its implications... Africa has its longest axis running North to South. This entails a great range of climatic difference. Because difference of climate is affected by vertical axis much more than the horizontal, it means that climatic difference within the African continent is very wide. This seriously affects the spread and exchange of inventions. What this means is that what is invented for use in a particular climatic condition cannot be used without problem in another nearby area, just because the climatic condition in the next area is very different (9).

With respect to the above argument, we ask: How many inventions on this planet are climate sensitive? Is it iron or steel, mineral deposits, or even human ideas that cannot tolerate climate change? Are we not using all sorts of products from other climatic regions of the world in Africa? Is it crops? James Morris Blaut (1999: p. 391), in criticizing Guns, Germs and Steel, noted examples of North-South diffusion of crops in the West- ern Hemisphere, most significantly the cultivation of maize in Peru and its adoption in North America, a significant blow to Diamond's axis thesis (adopted by Oguejiofor) on the difficulty of a North-South diffusion of crops. Oguejiofor, along with Diamond, continues that for Euro-Asia:

... where the longest axis is horizontal, any invention made in a place as far away as China can be used in Portugal because the climatic conditions of these very distant countries are not very variable. The spur given to the spread of invention in technological development seems to be evident. Where human beings can lay hands on and use beneficially technology developed from elsewhere, these are added to whatever they themselves were able to develop, and when the areas from which they are able to transfer inventions are large, it becomes a big booster to their sciento-technological level.

Oguejiofor sees the reason for easier traffic of inventions and technology across Euro-Asia as similar climatic conditions, even though it is also evident that the inventions reached as far as Southern United States within the same tropical climatic belt as most of Africa and climatically different from Euro-Asia. Agbakoba also discussed easy transfer of technology as one of the factors influencing speed of development, to show however that geography, but not exclusively geography, plays a role in development (Agbakoba, 2003: p. 564).

First, by completely absolving the African of any blame for under-development, and completely denying encomium for development on the part of those seen as developed, Oguejiofor's response has heavily political and therapeutic undertones. The second implication of arguing that African underdevelopment is a result of entirely extraneous factors is that we can do nothing about it. This is lame, and, contrary to his Africanist or antiracist intentions, is a great measure of defeatism. Thus, he sets out to tackle racism and ends in defeatism.

Thirdly, the theory is a pretension at realism, but even genuine realism per se is hardly a regulative virtue. A too-realistic ideal is merely an apology for the status quo (Neblo, 2007: p. 536).

Fourthly, the conclusion adds no epistemic value to the literature: what epistemic value do we derive from believing that we are helpless morons at the hands of a non-human universe which is allegedly in possession of a dictatorial and totalitarian scope of initiative? The only advise logical to Oguejiofor's submission is that we should bow down and worship nature (mountains, trees, rivers, the sun, moon, the winds etc) like our forefathers did in pleading with it to favour us, instead of seeking to master it, the same pre-scientific ideology that enabled thousands of Africans to be captured by a small band of Europeans in the first place (see, for instance, Wiredu, 1980: pp. 11-12, 61).

The fifth implication of Oguejiofor's entire work is that it is not possible in this universe that we can ever dream of approaching the West in terms of development. This discounts all the evidence of the millennia shift of civilizations (from Egypt to Greece, Fertile Crescent to China, China to Europe, Europe to North America, and the impeding shift from the West to East Asia). How does geography account for the fact that East Asia is positioning itself to represent this next shift? Are they extrahuman? One might think of objecting that East Asia had a once-upon-a-time civilization and technological prominence, as if Africa did not. In an epoch when we in Africa should be contemplating a similar escapade to that of East Asia, and possibly prepare to be a potential future recipient of the exchanging 
baton of world dominance, I do not see how this theory will benefit anybody. Like Hegel, Oguejiofor counts Africa out of the match of world civilization.

Oguejiofor's theory is essentially a repetition of the major arguments in Jared Mason Diamond's book, Guns, Germs and Steel (1997). Thus by examining Oguejiofor, we spare ourselves from examining Diamond in a length disproportionate to this paper, and just make a few summary remarks regarding Diamond's proposal and some of its implications, since it is the same geography, biogeography and history that spans the common theme. Diamond wrote the book to answer a question posed to him by Yali, a politician in Papua New Guinea: "Why is it that you white people developed so much cargo [that is, trade goods] and brought it to New Guinea, but we black people had little cargo of our own” (Diamond, 1997: p. 14)? In answering this question, Diamond refutes the view that Eurasian hegemony is due to any form of Eurasian intellectual, moral or inherent genetic superiority, and that geography decided history about 13,000 years ago when some societies settled to agriculture before others. Specifically, "Environment molds history," writes Diamond (1997: p. 352). All of the important differences between human societies are due to the nature of each society's local environment and to its geographical location. Human agency and culture are largely irrelevant.

Like Oguejiofor repeats, Diamond argues that geography in terms of axis of continents, unequal distribution of domesticable plants and animals and geographical barriers (which he sees as the ultimate factors); and then the unequal power and technology between societies as a result of these "ultimate" factors (which he calls the proximate factors) are responsible for the economic disparity between societies. The proximate factors, resulting from the ultimate factors, include the fallouts of economic and technological disparity, like slavery, colonization, etc (Diamond, 1997: p. 87). So Diamond argues that geography, biogeography and history are responsible for differences in economic development. But Diamond came under so much criticism (which cannot be accommodated into the space of this paper) that he had to make a U-turn in another book admitting and even emphasizing the importance of human decisions in response to geographical factors. He was accused of filling hundreds of pages of geography with speculation (Blaut, 1999: p. 395), completely ignoring the role of culture and human decisions (Hanson, 2005; Tomlinson, 2008; Smith, 2001: par 8; Blaut, 1999: p. 395) and of treating natural determinants of plant ecology as somehow determinants of human ecology (Blaut, 1999: p. 395). ${ }^{1}$

The good point of Diamond's geographical/biogeographical account of the fates of societies is the attempt to deal a final blow to hereditarian/racist accounts of history, but you cannot simply use geographical fatalism to replace biological fatalism. It is a movement from one reductionism to another. Several times he says that the only alternative theory to his is racist. But this is false, since there are too many human and cultural factors to highlight for developmental differences without implying innate racial differences of any kind. The charge of reductionism merits a little elucidation. Diamond's presentation assumed that this is a controlled experiment, and that once these factors (geography, biogeography) are present, then development is automatic. But this does not follow, since it overlooks

${ }^{1}$ For a detailed review of Jared Diamond's Guns, Germs and Steel and its growing influence on African scholarship, see my article "Africa and Geographical Determinism” (forthcoming). the human agency. It is akin to saying that a man will automatically eat food when he is hungry. What if he decides to fast? The free will is not servile to such determinism. It is, at least, logically possible that the environmental conditions prescribed by Diamond as encouraging development could be present and the human agency will decide not to develop, just as it is a fact that the human agency can decide to transcend discouraging environment.

In a later book titled Collapse: How Societies Choose to Fail or Succeed, Diamond tries to restore human agency and put a human face on the interplay between society and the environment. He uses a "framework" when considering the collapse of a society, consisting of five "sets of factors" that may affect what happens to a society: environmental damage, climate change, hostile neighbors, loss of trading partners, and the society's own responses to its environmental problems. In order words, two of the factors are environmental, three are human. Since he does not take account of this reverse on the part of the man on whom he theoretically relies, it is open to question whether Oguejiofor did not encounter this book, or encountered and ignored it.

Most importantly, the entire debate seems to be based on the economistic conception of development which is “... lopsided and terribly inadequate... as it fails to come to grips with the complex nature of human nature, society and culture" (Gyekye, 1994: p. 45). This complexity calls for a comprehensive, not segmented, approach, an approach that will see development as capacity to perform satisfactorily the functions appropriate to an object, such as society or institution (Gyekye, 1994: p. 48) in terms of adequate responses to the entire existential conditions in which human beings function, conditions which encompass the economic, political, social, moral, cultural, intellectual and others. All these conditions are greatly helped by a congenial political climate and a viable ethical and cultural framework (45). Gyekye’s "environment” is not just physical surroundings but entire socio-cultural conditions (48). Development is a multi-dimensional and integrative concept which cannot be measured by Gross Domestic Product (GDP). This fact has been appreciated by the United Nations Development Programme which has shifted its international calibration paradigm from measuring GDP to measuring HDI (Human Development Index). Economic growth is only a tip of a complex iceberg, and economic development constitutes only a species of the genus development which is a comprehensive concept that encompasses the economic, political, moral, cultural etc. A species is never identical with its genus (Gyekye, 1994: p. 49). Relationships between these species might not be logical since one might not be a sufficient condition for the other. Example, economic growth might not imply higher morality or distributive justice. The relationship could also be logical, like when a culture of bush burning undermines agricultural economy, when a culture of impunity undermines the development of public infrastructure, or when a politics of violence keeps away foreign direct investment. ${ }^{2}$ However, it is generally agreed that even though political development is not a sufficient condition for economic development, it is a necessary one (Gyekye, 1994: p. 50). But politics is an extension of ethics.

Owing to growing scholarly dissatisfaction with the economistic notion of development, Martin Ajei (2011: p. 2) has

\footnotetext{
${ }^{2}$ We do not here employ the word "culture" in the ossified sense of extant ancient practices, but in the sense of dominant behavior in a given place and time.
} 
reiterated Matinussen's suggestion that the issue of development should begin with an understanding of what 'development' should mean. This necessitates a distinction between the concept, theory and strategy of development. This distinction prioritizes the discussion to begin with the "concept" of development which should contain the answer to what "development" is. The concept of development is value-laden in terms of what the subject prefers to call development, but it is also ethical since it encapsulates notions of what ought to be understood as development. Settling questions of concept (and thus of goal) engenders a move to theory and then to strategy. Whilst theory and strategy might be shared by the scientific disciplines, the conceptualization of development is predominantly philosophical. An example of trying to discuss the concept is Gyekye's cited position above. Oguejiofor's challenge ignores the concept of development, or rather assumes its economistic interpretation, an interpretation that gives rise to the developed/under-developed categorization, a categorization on which he assumes that Africa has a predicament in the first place, and then he goes directly into theory. Even worse, most governments of the world take concept and theory for granted and delve directly into 'strategies for economic outcomes', not knowing that it is only a component of a whole, only meant to be a consequence of the functioning of a whole. To be sure, Abgakoba's theory, which appears to be in line with Gyekye's conceptual supposition, calls for ethical and political strategies of re-orientation which are not immediately economic by outcome, but prioritizes good function of society as goal. If there is any strategy suggested by Oguejiofor's theory, it is, first, self-absolution, followed by resignation to "fate". The "fate" is "underdevelopment". Let us, however, leave to another article a fuller development of the concept of development and, for the purposes and restricted space of this article, evaluate the claims that have been made regarding the relationship between nature, human agency and economic development.

\section{Between Nature and Human Agency in African (Economic) Development}

The statement that African economic development is hampered by unfriendly weather seems to be opposed by history and present reality, going by inventory of great natural disasters leaving Africa untouched and the extreme temperate conditions of the Nordic countries with long months of snow making it virtually impossible to do anything with the soil. For instance, Holland up till the 11th century was an extremely inhospitable place and peat-bog on which absolutely nothing would grow, plagued by constant floods and in which any human endeavor was time and time ruined by floods and by high levels of salt water (Barendse, 2000: par 11). Generation on generation of Dutch farmers gradually dug away the peat, built canals to drain the marches and built dikes to stop the inundations, so that about 500 years of effort gradually moved the supposed "environmental wall” to turn the country into Europe's most densely populated one. Perhaps it is this environmental hostility that sped up the Nordic's innovation with steel and technology. It is obvious that geographic hostility has the opposite effect to what Oguejiofor suggests: it actually speeds up innovation.

Oguejiofor has also to explain how geography accounts for development disparities within the same region. Is it due to geography that Ghana has taken a local comparatively decisive turn in attracting direct foreign investment, both in education and industry? Is it due to geography that previously unknown South Korea is now hitting hard at the whole world in automobile and electronics innovation? Or is it a question of conscious human decisions, which are always encased in ideological orientations as Agbakoba insists?

Oguejiofor cites Diamond to show that in terms of biogeography, hardly any plant and animal species originated from Africa. In his words:

Again from the availability of domesticable plants and animals Africa also suffers a huge disadvantage. For example the world distribution of large-seeded grass species shows there are only 4 in the whole of sub-Saharan Africa, while there are 11 in the Americas and 33 in the zone designated as West Asia, Europe, North Africa and Mediterranean zone. Similarly in the distribution of candidate-animals for domestication... shows that there are originally 13 in Euro-Asia, one in the Americas and none at all in the whole of Africa. Of the five big herbivorous domestic animals, Sheep, Goat, Cow, Pig, Horse, none was originally found to be home to sub-Saharan Africa. The big domestic mammals had enormous influence on the onset and the spread of food production with consequence on the evolution of science and technology (2009: pp. 9-10).

The above statistical submission, which Oguejiofor borrows from Diamond, is simply questionable since it contradicts the theory of Africa as the Eden of human existence: how is it that man originated from Africa and most of all that he needs to exist originated from elsewhere? And where did Diamond get this information (or intuition) from, especially since it is being questioned by majority of geography reviews?

Diamond tries hard to encompass everything under geography and biogeography, but his analysis unwittingly reveals the possibility of using ideological measures to correct what has been done or undone by extraneous factors. According to Levinas (2011: par 19):

Prof. Diamond sweeps other facts that resist geographic pigeonholing under the QWERTY principle. The first typewriters featured the awkward QWERTY keyboard, meant to slow typists down so as not to jam the then-primitive typing mechanism. But so many typists learned QWERTY, and passed it on to future typists, that it remains entrenched even though electronic word processing permits more ergonomic keyboard arrays. Just so, suggests Prof. Diamond, many of the "idiosyncrasies" that may bias some cultures against innovation may be due to accidents that arose for "trivial, temporary local reasons", and became fixed as "influential, long-lasting cultural features."

If, according to Diamond, what was caused by geographical accident (like bias against innovation) has come to endure as culture (or worldview/ideology), then all that is needed is to revisit the culture/worldview/ideology, in this case to begin to cultivate an orientation for innovation, or, in Wiredu's opinion, the habits of exactness and rigour in thinking, the pursuit of systematic coherence (Wiredu, 1980: p. 32), which is likely to discourage superstition (Wiredu, 1980: pp. 15-16). To be sure, superstition is in every society, but how can a society develop in any way if superstition is very predominant? To be sure, a predominantly superstitious society can be identified if people generally see achievement as a largely divine event instead of a marriage between opportunity and long-drawn preparation, which in turn gives rise to a very high demand for fortunetellers, diviners, prophets and prosperity pastors. Or is this not a hybrid worldview which flows from an amalgamation of traditional superstition, materiality, and modern economic surplus? 
Is it something which we cannot address as philosophers? Or has it been permanently ensured by geography and history?

In Oguejiofor's nationalistic scheme, it must be proven that the African is not connected at all with his predicament. Anyone who attempts to mention human agency as in any way contributing to (and possibly as capable of solving) the African predicament is either a racist or an African self-defeatist. But the history of societies has no inventory or knowledge of a perfect people. When Diamond was taken to task in an interview about the immutably deterministic implication of his book (you either become rich or poor depending on where you are born; you can do nothing about it), he immediately acknowledged the power of human agency to change one's fate and referred to Malaysia, Taiwan and Singapore, to show, in his words, that "...poverty is something you can do something about” (Lovgren, 2005: par 16). And it seems to me that these countries did not radically change their state of affairs by government paper policy alone. Something must have happened to the collective mind, very much like Agbakoba's insistence on ideological change and self supercession (Agbakoba, 569). Any analysis of the roots of advancement of any human society must take account of both environmental and human agencies. To pose the African as merely a victim of all the negative circumstances in the world is to assume fatalism, defeatism and no regard for free will, human agency and human decision.

Oguejiofor's entire article clearly aims to show that there can never be anything wrong with African worldviews, just as, by implication, there can never by anything wrong with any worldview. All we need to do is understand the worldview in its context. But it seems that this thing about context has gone too far, everything is understandable in context. Apart from the fact that it seems to be an overstretching of Okere's contextualization of philosophy, it suggests cultural relativism, which is the theory that every culture is equally valuable and that an act must be good when its situation in a culture is appreciated, but cultural relativism can very easily lead to moral relativism and thus runs the danger of jettisoning morality and absolving any kind of act whatsoever under the banner of "cultural context".

Is a perfect worldview even theoretically possible, that is, one that has no malfunctions or in need of correcting and adaptation, even to changing circumstances and evolving reality? Theoretically it seems impossible, and factually the history of mankind shows that such a static and perfect worldview does not even exist. Oguejiofor's cosmetic protection of the African pristine worldview also smells unpleasantly of the romantic dogmatism of ethno-philosophy.

What Oguejiofor is also inadvertently prescribing is that we should simply resign ourselves to the level and speed of development that geography, biogeography and previous history happen to foist upon us. We can simply do nothing about this.

Another thing that Oguejiofor is saying is that once geography, biogeography and historical factors are favourable, then development will automatically take place. Another determineism, this that all human beings are either determined to develop or not. There is nothing that conscious decisions can do about it, now or in the future, on the personal or societal levels. There is a fallacy of contingency in assuming that once these extraneous factors are present, there must be development.

If one wonders why Oguejiofor uncritically adopts Diamond's geo-historical determinism, the answer may be found in Chapter 5 of his Philosophy and the African Predicament. This is a chapter that he devotes to enumerating the historic inability of philosophy to make meaningful contribution to society (and least of all the African society), and sees the verificationism in science as more capable of solving society's problems, even the ideological and moral ones (Oguejiofor, 2001: pp. 137-138). In this chapter (135-137), every single philosopher in the history of philosophy failed in his objective, and Oguejiofor tries to explain this (Plato's utopia, Aristotle's aristocracy, Aquinas' monarchy, Hobbes' totalitarianism, Machiavelli's amorality, Hegel's Prussian Chauvinism, Marx's most disastrous Marxism, the unabashedly senseless and unrealistic Marxist dogmatism of Senghor, Nkrumah, Nyerere, Awolowo and Hountondji, etc.). But we may remind Oguejiofor that John Locke is the father of liberalism and the foundation of the American constitutional liberalism which is now as successfully and globally practiced as communism has become the most globally disastrous (we may even see John Locke as patron of the Arab Spring), and that Francis Bacon laid the frameworks for the inductive method with which science has recorded colossal material achievement, the same science that Oguejiofor admires so much, and that the central effect of Karl Marx all over the world is the humanization of the worker, without which the worker's wage (including that of university professorship) will be too mean to venture into the enterprise and thus kill societal progress. He concludes that:

... there is nothing that philosophy in any direct term can do, any more than other disciplines, or in addition to them, to aid development, if development is ultimately understood in economic and scientific-technological terms. There is little of special knowledge that philosophy can impart in spite of the avowal of its practitioners, be it knowledge of morality, of politics or of logic which will immediately, and surely, make the subject of that knowledge to be an effective agent of development [bold emphasis mine] (143).

This is a chapter where Oguejiofor raises the same kind of foundational doubt about philosophy as Oyebola (1976) raised about the black man. But he equivocates by acknowledging that one very special feature of philosophy is the entertainment of a barrage of various views on an issue (Oguejiofor, 2001: 141145) and makes a completely contradictory U-turn towards the end of the chapter by advising African students in philosophy to engage more in issues of concrete relevance on the continent like ethnicity, religion, morality, politics and economics (146).

What is certain is that if environment alone is enthroned as sacrosanct to development and human agency is denied any role in the fate of societies, then human remedy of any kind is equally denied. And if human remedy of any kind is denied, then there is no need for a philosophy of African development, and ultimately for African philosophy, a field for which Oguejiofor claims professorship.

We agree that geography and history (but not biogeography for want of statistical credibility) affect the fate of societies, but they cannot become the sufficient conditions and ultimate explanations for the fate of societies as Oguejiofor attempts to explain for Diamond (Oguejiofor, 2009: p. 8). We are not arguing against these things, but they cannot be all that there is. The prehistoric agricultural head-start incident is not sacrosanct and not eternally binding.

The basic assumption that informs Oguejiofor's denial of the human African of any stake in his development is that if we say that Africans have one or two cultural or ideological things to correct in lieu of development, in other words if the African himself apart from his surroundings is linked in any way to his 
underdevelopment, it proves his inferiority to the white man. But this is a mistaken carry-over of anti-racial over-exuberance. That A might personally have anything to do with his class performance and B something to do with his class non-performance does not mean that A is inherently superior in intelligence to $\mathrm{B}$. It could simply mean that $\mathrm{B}$ needs to revisit his modus operandi. Even if in addition to his personal efforts, A had a head start with a middle or higher class background and surrounding, healthy nutrition, excellent early education and the most expensive childhood home tutors, it is not impossible for $\mathrm{B}$ with a disadvantaged background to challenge A with some very crucial decisions about his academic life. Even if Africans started off late, are partly responsible for the speed of their economic progress by their present way of seeing the world, and may need to revisit their largely pre-scientific ethics, ideology and worldview, it does not mean in any way that Africans are inferior to Europeans. It will only mean that they are doing what the Europeans did during the Renaissance. If Oguejiofor's hatred for racism (which is understandable) means that we cannot take one or two critical looks at our traditional values in lieu of clashing with the concept of statehood inherited from a culturally different Europe, then it is a mistaken assumption that informs his entire write-up.

Oguejiofor concludes that it cannot be true that a worldview is the cause of the under-development of a continent of half a billion people (2009: p. 1). He misinterprets Agbakoba as referring to a single worldview for the entire continent. But Agbakoba's work concentrates on two ethical components of the worldview of a cultural-linguistic group in Eastern Nigeria. Even at this, the ethical fallout in the region which Agbakoba examines is easily noticed in many parts of the continent. More importantly, Oguejiofor's objection emerges from his'pristine' presentation of worldview. This "pristine" account is a gross misrepresentation of present African worldview, which is a modern crisis product of the clash between Western, Eastern and traditional worldviews. Take the religious clashes for instance. A religion is also a worldview (Oguejiofor, 2009: p. 3), and they are clashing in Africa, to the extent of putting material development on hold. This poses a challenge for philosophy of religion. Already, there is a call to drop or mitigate supernaturalism, since it can lead to situations where policies that lead to manifestly human suffering are advocated or pursued with a sense of piety and rectitude (Wiredu, 1980: pp. 5-6). Culturally also, the clash between traditional African ethical values and the imposed modern statehood is not the fault of the African. Here, Agbakoba's concern strikes a chord with Ekeh's two (conflicting) publics in Africa (1975: p. 105) and Nkrumah's crisis of the African conscience, a conscience made up of traditional, Islamic and Euro-Christian influences, which calls for a new ideology solidified in a philosophical statement (Nkrumah, 1974: pp. 70, 78-79). Even Wiredu (1980: p. 23) referred to this when he wrote that “... the phenomenon of belonging at once to two worlds... was unknown when this ethic evolved. Little wonder if the new dualism causes a kind of ethical schizophrenia in some spheres of conduct”. Certain ethical values worked well in the traditional society. The only difference is that the scope of operation has changed. All it means is that the African has to find a way to begin to shift his primary allegiance from his immediate primordial origins to his modern civic nation. This shift means that the state must replace his primordial community as his basic community. This shift is a necessary prelude to improving his ethical conception of the state, if the project of the state in Africa is to stop being a shadow. How this shift could be made possible is subject to continued scholarship. These are issues to be dealt with. But if we are to go by Oguejiofor's theory, then we are stuck with this situation. It has been ensured by geography and history. Europe may have gained head starts in agriculture and technology and consequently colonized Africa thereby imposing their structures on ours, but the place of the human agency is that we must contend critically and realistically with the aftermath of this development, instead of sheltering lazily on geographical fatalism. In other words, we must acknowledge that we have the power and initiative to turn things around, no matter how painful and gradual, even as they presently are.

\section{Concluding Remarks}

To summarize, Agbakoba's list of the causes of African underdevelopment includes geography, history and ideology. He sees the relationship between the environment and the human as two-way: man can be affected by the environment surrounding him, but he can also make the environment to submit to him, not merely to adapt to it and its whims as Oguejiofor writes (Oguejiofor, 2009: p. 8). Oguejiofor acknowledges only geography, biogeography and history as ultimate explanations of the fate of societies. I think that Oguejiofor's submissions are too Africanist in the overriding desire to dislodge racism, and therefore, sentimental and reactionary, which are obviously not enough ingredients to crack the problem of development. Inadequately reasoned nationalistic and anti-racial sentiments are too partisan and unhelpful in cracking problems that are much more logical and strategic. If you want to solve your problem, you might reasonably apportion blames at some points along the line, but you do not both begin and end by looking for scape goats elsewhere. It means that you have no problem to solve.

As opposed to Oguejiofor's approach, I think the task is not to slide from reason to sentiment, or to engage in political ballistics, but to get more critical and constructive with our issues, in other words, get more responsible as academics. It is time we concentrate on addressing our own issues, for nobody else will do this for us.

This is therefore the aim of philosophy: continuous and dispassionate scrutiny and critique (of the self and the other where it applies), and Oguejiofor's fear that the philosopher's efforts may take hold only long after he has died (Oguejiofor, 2001: p. 135), as a discouragement from devoting our mental energies to thinking critically about our problems, is also lame and shortsighted. Constructive philosophical activity produces what we call post-hummus value, which is responsible for the bulk of societal progress. It is obviously the next most important ideological value to address viz a viz African development.

Reacting to the fatalistic reverberations of Guns, Germs and Steel, Bill Gates calmly writes that:

The book reminds me that innovation sustains success while complacency leads to stagnation and decline-a lesson I try to keep in mind every day. In early human history, technological advantages were built on the availability of certain plants, animals and geographies. In today's emerging information society, the critical natural resources are human intelligence, skill and leadership. Every region of the world has these in abundance, which promises to make the next chapter of human history particularly interesting.

In this connection, Philip Coelho (1998: p. 1181) remarks that: 
Another error that Diamond-and many others-makes is to assume that the game is over. The author writes about the eventual dominance of Europeans and their descendants as if it were permanent. But, if we are to believe Diamond, East Asian countries with open and honest capitalist systems have a density advantage over the West. The next millennium may see a re-ranking of regional economic advantages. For someone who espouses the long run (with a vengeance) approach to history, Diamond curiously ignores it when looking into the future.

Such perspectives deny Oguejiofor's emphasis on the ineptitude of the African in the face of his adversities, which, as we observed, leads to resignation. As evidence of this, the most constructive venture that he can offer about "the African predicament" is that it is "... really getting worse" (Oguejiofor, 2009: p. 1). On the other hand, Gates and Coelho both see the significance of human agency and decision in development.

Thus we can distinguish two approaches to development history: that of Diamond or geography which reaches back in time into millennia and in space across continents and super continents (which we can here call the macro approach to development), and that of general social scholarship which reaches back in time only a few decades and hundreds of years and in space across countries, placing more weight of development on human decisions, quality of government, political and economic policies (which we can call the micro approach for the purpose of this work), etc. The micro approach, as reflected by Gates, Coellho and the social scholars, reflects the place of human decisions and actions, in short, the human agency in the more immediate and qualitative/quantitative step to step approach to development. Are these two approaches competitive or cumulative? Peter Temin (1998: pp. 406-407) thinks that they complement each other and collaborate to make a more complete explanation of development. So Diamond's macro approach only answers part, not all of Yali's question. In fact, Diamond fails to give Yali the most significant "micro" answer, which provides ample room for individual initiatives and human decisions/outcomes. If anything, Diamond completely destabilizes Yali, who only sought to gain some light on, not only what is responsible for his people's "lack of goods", but more importantly, how "their goods" can be improved. David Frum (1998: p. 135) notes that history has its victims, of course, and Diamond's account of how those victims became victims is powerful and illuminating. But the best way to deal with one's victimhood is by putting it behind one, rather than lounging upon it and indulging it.

The macro approach may explain why regions around the world have the same general pattern of development as determined by primordial agricultural head starts, but falls behind the micro approach in explaining why certain countries within the same region — often immediate neighbours — vary radically in levels of development. The macro approach may explain why Nigeria, Ghana and Liberia are not like France, Germany and England, but the micro approach explains why war-ravaged Liberia and Congo are behind Nigeria and Ghana. The micro approach explains why the Asian Tigers have defied Diamond's geographical determinism and bounced into full global reckoning (and possibly toward dominance). The micro approach also explains the chronological possibilities of development as to why, for instance, it is possible for Liberia to take steps to be like Ghana within a decade or two, but not immediately like France which will take longer cumulative of striving with the current potentials at her disposal. But the indispensability of the micro approach is that if Liberia does not begin to make the quality of economic and political (and by implication, cultural and ideological) decisions requisite for growth, they will not set out to pace up with either Ghana or France at all. Indeed, both the present and future depend on the micro approach; and the macro approach, which depended on the favourable nature of geographical climate to the traffic of crops and animals tens of thousands of years ago, has ceased to be decisive. So, do we wait for geography and history to correct themselves in our favour, or do we take the initiative into our hands?

\section{Acknowledgements}

The author would like to thank Hussein Inusa, Richmond Kwesi, Dr Martin Ajei and five anonymous reviewers for their helpful comments in earlier versions of this article.

\section{REFERENCES}

Agbakoba, J. C. (2009). Philosophy and traditional african ethics: The problems of economic development. Revista Portuguesa de Filosofia, 65, 549-576.

Agazzi, I. (2010). Africa: "Free trade in natural resources bad for development”. URL (last checked 27 June 2012).

http://www.afronline.org/?p=7273

Ajei, M. (2011). Africa's development. Berlin: Lambert Academic Publishing.

Austin, S. (2011). Japan seeks a resilient energy policy. URL (last checked 27 June 2012).

http://oil-price.net/en/articles/japan-seeks-resilient-energy-policy.php

Barendse, R. J. (2000). Review of guns, germs and steel. URL (Last checked 7 July 2011).

http://www.j-bradford-delong.net/econ_articles/reviews/diamond_gu ns.htm

BBC News Africa (2102). Uganda abandons landslide rescue bid for buried. URL (last checked 25 August 2012). http://www.bbc.co.uk/news/world-africa-18592927

Blaut, J. M. (1999). Environmentalism and eurocentrism. The Geographical Review, 89, 391-408. doi:10.2307/216157

CNNMoney (2012). World's largest economies. URL (last checked 27 June 2012).

http://money.cnn.com/news/economy/world_economies_gdp/

Coelho, P. R. P. (1998). Review of guns, germs and steel. The Journal of Economic History, 58, 1179-1181. doi:10.1017/S0022050700022178

Diamond, J. M. (1997). Guns, germs, and steel: The fates of human societies. New York: W. W. Norton \& Company.

Diamond, J. M. (2005). Collapse: How societies choose to fail or succeed. New York: Viking Press (Penguin Group).

Ekeh, P. (1975). Colonialism and the two publics in Africa: A theoretical statement. Comparative Studies in Society and History, 17, 1. doi:10.1017/S0010417500007659

Eisele, C. (2007). Africa’s natural resources: Blessing or curse? URL (last checked 27 June 2012).

http://craigeisele.wordpress.com/2007/09/09/africas-natural-resource s-blessing-or-curse/

Frum, D. (1998). Review of Jared Diamond: How the West Won: History that feels good usually isn’t. Foreign Affairs, 77, 132-135. doi: $10.2307 / 20049056$

Gates, B. (1997). Review of guns, germs and steel. URL (last checked 7 July 2011).

http://www.j-bradford-delong.net/econ_articles/reviews/diamond_gu ns.htm

gyekye, k. (1994). taking Development Seriously. Journal of Applied Philosophy, 11, 45-56. doi:10.1111/j.1468-5930.1994.tb00089.x

Hanson, V. D. (2005). Decline and fall. National Review.

Levinas, M. (1998). Squaring the circle (review of guns, germs and steel). American Renaissance. URL (Last checked 7 July 2011). 
http://www.lrainc.com/swtaboo/stalkers/ml_ggs.html

Lovgren, S. (2005). “Guns, germs and steel”: Jared Diamond on geography as power, interview for national geographic news. URL (last checked 7 July 2011).

http://news.nationalgeographic.com/news/2005/07/0706_050706_dia mond.html

McNeill, J. R. (2001). The world according to Jared Diamond. The History Teacher, 34, 165-174. doi:10.2307/3054276

Neblo, M. (2007). Family disputes: Diversity in defining and measuring deliberation. Swiss Political Science Review, 13, 527-557. doi:10.1002/j.1662-6370.2007.tb00088.x

Nkrumah, K. (1974). Consciencism, philosophy and ideology of decolonization and development with particular reference to the African revolution. London: Panaf.

Oguejiofor, J. O. (2001). Philosophy and the African predicament. Ibadan: Hope Publications, Ltd.

Oguejiofor, J. O. (2009). Is the African worldview responsible for the African predicament? Uche, 15, 1-13.

Oguejiofor, J. O. (1996). The influence of Igbo traditional religion on the socio-political character of the Igbo. Nsukka: Fulladu Publishing Co.

Oyebola, A. (1976). Black man's dilemma. Ibadan: Board Publications.

Rushton, J. P. (1999). Review of guns, germs and steel. Population and Environment, 21, 99-107. doi:10.1023/A:1022157211445

Serequebehran, T. (1994). Hermenutic of African philosophy: Horizon and discourse. London: Routledge.
Sharpe, M. E. (1998). Guns, germs and steel: Review. Challenge, 41, 118-124.

Smith, C. A. (1999). Review of guns, germs and steel. URL (Last checked 7 July 2011).

http://www.j-bradford-delong.net/econ_articles/reviews/diamond_gu ns.htm

Temin, P. (1998). Review of guns, germs and steel. The Journal of Interdisciplinary History, 28, 405-415.

Tomlinson, T. (2009).Review: Guns, germs and steel: The fates of human societies. Institute of Historical Research. URL (last checked 13 August 2012).

http://www.history.ac.uk/reviews/paper/diamond.html

United States Energy Information Administration (US IEA) (2012). Country analysis briefs (Japan). URL (last checked 27 June 2012). http://205.254.135.7/EMEU/cabs/Japan/pdf.pdf

Von Sivers, P. (2000). Review of guns, germs and steel. URL (last checked 7 July 2011)

http://www.j-bradford-delong.net/econ_articles/reviews/diamond_gu ns.htm

Waldie, P. (2012). Japan sits atop deadliest section of ring of fire. URL (last checked 25 August 2012).

http://www.theglobeandmail.com/technology/science/japan-sits-atop -deadliest-section-of-ring-of-fire/article572438/

Wiredu, K. (1980). Philosophy and an African culture. Cambridge: Cambridge University Press. 